To cite: AC Diala 'The shadow of legal pluralism in matrimonial property division outside the courts in Southern Nigeria' (2018) 18 African Human Rights Law Journal 706-731 http://dx.doi.org/10.17159/1996-2096/2018/v18n2a13

\title{
The shadow of legal pluralism in matrimonial property division outside the courts in Southern Nigeria
}

\author{
Anthony C Diala* \\ Senior Lecturer, Department of Private Law, University of the Western Cape, \\ South Africa
}

\section{Summary}

Scholarly interest in the co-existence of normative orders in African social fields tends to focus on conflicts arising from the interaction of customary law with state law. This article takes a different path by revealing the normative influence of state law on actors involved in matrimonial property division outside the courts in Southern Nigeria. Based on individual interviews and focus group discussions with female divorcees, their parents, clergy, traditional leaders, NGOs and social welfare officials, it analyses inequalities in property division under customary law, arguing that these inequalities often lead to 'dignity takings'. It reveals how the Social Welfare Department, a government agency mandated to champion the interests of women and children, plays a prominent role in the privileging of gender, class and women's dignity. Spurred by statutes, this department increasingly orders men to divide matrimonial property and/ or to pay compensation to women. Its quasi-judicial orders on marriage gifts, properties bought by women, and child custody potentially contribute to 'dignity restoration' for women infantilised by the customary law of matrimonial property. By revealing the driving forces behind shifts in the traditional philosophy of matrimonial property, the article demonstrates how non-judicial dialogue between state law and customary law facilitates a living customary law of marital property division in Southern Nigeria.

Key words: customary law divorce; dignity takings; matrimonial property; Social Welfare Department; Nigeria

* $\quad$ LLB (Enugu State University of Science and Technology) LLM (Human Rights and Democratisation in Africa) (Pretoria) PhD (Cape Town); adiala@uwc.ac.za. I gratefully acknowledge the financial assistance of the African Humanities Programme of the American Council of Learned Societies. 


\section{Introduction}

Legal pluralism in Africa is generally regarded as the co-existence of international, state, customary and religious laws within a population or social field. ${ }^{1}$ Academic interest in this co-existence tends to focus on the conflicts arising from customary law's interaction with the transplanted European laws that developed into state law. ${ }^{2}$ This interest is understandable, given the problems caused by the wholesale transplantation of relatively sophisticated European laws into agrarian political economies. As Merry observed, 'the imposed law, forged for industrial capitalism rather than an agrarian or pastoral way of life, embodied very different principles and procedures ... [and] overlooked, to a large extent, the complexity of previous legal orders'. ${ }^{3}$ Arguably, this complexity is partly traceable to the close link between customary law and the foundational values which prompt, inform and guide the manner in which people apply customs. Unfortunately, judges and policy makers do not pay sufficient attention to these values. ${ }^{4}$ For example, customary law heirs inherited property alongside duties such as care for a deceased's dependants and the preservation of the ancestral home. ${ }^{5}$ However, when interpreting customary law, judges applied formal rules of inheritance without their foundational duties, sometimes relying on distorted versions of customs presented by chiefs and headmen. ${ }^{6}$ Codified customs, textual descriptions and judicial precedents became known as official customary law, raising conflict of law problems that encouraged an antipodal approach to legal pluralism. ${ }^{7}$ In a marked departure from mainstream scholarship, this article primarily aims to reveal dialogue between state law and customary law in the context

1 GR Woodman 'Legal pluralism in Africa: The implications of state recognition of customary laws illustrated from the field of land law' in $\mathrm{H}$ Mostert \& $\mathrm{T}$ Bennett (eds) Pluralism and development: Studies in access to property in Africa (2012); PS Berman Global legal pluralism: A jurisprudence of law beyond borders (2012).

2 See, eg, M Pieterse 'Killing it softly: Customary law in the new constitutional order' (2000) 33 De Jure 35; A Hellum 'Human rights and gender relations in postcolonial Africa: Options and limits for the subjects of legal pluralism' (2000) 25 Law and Social Inquiry 635 at 637.

3 SE Merry 'Legal pluralism' (1988) 22 Law and Society Review 869.

4 AC Diala 'Lessons from South Africa on reform of the customary law of inheritance in Nigeria' (2014) 14 African Human Rights Law Journal 633.

5 As above; C Fombad 'Gender equality in African customary law: Has the male ultimogeniture rule any future in Botswana?' (2014) 52 Journal of Modern African Studies 475.

6 L Mbatha 'Reforming the customary law of succession' (2002) 18 South African Journal on Human Rights 259; Onyibor Anekwe \& Another v Maria Nweke (2014) All FWLR (Pt 739) 1154, Ukeje v Ukeje (2014) 11 NWLR (Pt 1418) 384-414; Bhe v Magistrate Khayelitsha \& Others 2005 (1) BCLR 1 (CC).

7 CN Himonga \& C Bosch 'The application of African customary law under the Constitution of South Africa: Problems solved or just beginning' (2000) 117 South African Law Journal 319; TW Bennett "'Official" vs "living" customary law: Dilemmas of description and recognition' in A Claassens \& B Cousins (eds) Land, power and custom: Controversies generated by South Africa's Communal Land Rights Act (2008); J Bekker \& GJ van Niekerk 'Broadening the divide between official and 
of matrimonial property division outside the courts. Two arguments accompany my aim.

First, although I acknowledge the seriousness of conflict of laws, I believe that legal pluralism in Africa is adaptive in nature. Accordingly, it should be approached from the perspective of dialogue between state law and customary law. This belief is informed by my empirical evidence, which reveals state law's considerable influence on the normative behaviour of individuals who observe customary law. Interestingly, this influence transcends the decisions and pronouncements of courts in Southern Nigeria. An example of this influence is the best interests of the child principle, which I discuss in part four of the article.

Second, customary law's denial of women's matrimonial property rights during divorce fits the bourgeoning jurisprudence of 'dignity takings'. The notion of dignity takings is a relatively recent entrant into socio-legal theory. It developed from Atuahene's striking book We want what's ours: Learning from South Africa's land restitution program. ${ }^{8}$ This book portrays the colonial and apartheid era land dispossessions in South Africa as dignity takings as they involved not only deprivation of property but also dignity. It further argues that South Africa's attempts at confronting the underlying dehumanisation, infantilisation and political exclusion that underpinned land dispossessions is a 'dignity restoration' measure, which transcends the usual remedy of providing compensation for physical property losses. ${ }^{9}$ In a later contribution Atuahene conceptualised dignity takings as 'when a state directly or indirectly destroys or confiscates property rights from owners or occupiers and the intentional or unintentional outcome is dehumanisation or infantilisation'. ${ }^{10}$ I argue that the denial of women's matrimonial property rights during divorce results in dignity takings as it ignores women's economic agency and capacity to make informed decisions regarding their contributions to matrimonial property. By revealing how a government agency navigates the customary law power inequalities that inform dignity takings in matrimonial property disputes, I explore whether the interventions of this agency fit the notion of 'dignity restoration'.

While it is relatively easy to conceptualise dignity takings beyond land dispossessions, it is difficult to conceptualise dignity restoration. Historically, those at the receiving end of property dispossessions are

living customary law' (2010) 73 Journal of Contemporary Roman-Dutch Law 679; JC Bekker \& IP Maithufi 'The dichotomy between "official customary law" and "non-official customary law"' (1992) 17 Journal for Juridical Science 47; M Pieterse 'Reform of the South African customary law of succession: Final nails in the customary law coffin?' in J Fenrich et al The future of customary law (2011) 336.

8 B Atuahene We want what's ours: Learning from South Africa's land restitution program (2014).

$9 \quad$ Atuahene (n 8) 796.

10 B Atuahene 'Takings as a socio-legal concept: An interdisciplinary examination of involuntary property loss' (2016) 12 Annual Review of Law and Social Science 171 at 178 . 
poor and vulnerable individuals, who are often victims of conquests, conflicts, colonialism and apartheid. More recently, communism and capitalism, which often masquerade as wealth distribution and a free market, respectively, have contributed to property dispossession under the legal banner of public purpose and just compensation. However, although 'material compensation is an appropriate remedy' in most property dispossessions, it 'is not enough' because the victims lose 'more than their property - they [are] also deprived of their dignity'. ${ }^{11}$ Atuahene argues that 'the appropriate remedy for a dignity taking is "dignity restoration"', which she defines as a 'remedy that seeks to provide dispossessed individuals and communities with material compensation through processes that affirm their humanity and reinforce their agency ${ }^{\prime 2}$ To achieve adequate dignity restoration, therefore, remedies for dignity takings must be articulated through mechanisms that respect the individuals who are harmed by such takings, thereby affirming their humanity and agency.

In extrapolating the notion of dignity takings to the customary law of matrimonial property in Southern Nigeria, I argue that dignity takings occur on two fronts. The first, which does not directly involve the state, occurs when men rely on customary law to rob women of matrimonial property during divorce. Given that women directly and indirectly contribute in the acquisition of marital property, denying them a right to benefit from this property denies their status and agency as equal partners in the marriage project. As I explain later, this denial equates to the infantilisation of women. The second front on which dignity takings occur is the non-existence of regulatory conditions that enable divorcing women to claim marital property. To limit and prevent dignity takings, married women must obtain agency through matrimonial property legislation, and/or inclusion of matrimonial property rights in the Nigerian Constitution. Such legislative measures will affirm women's status as property rightsbearing individuals in cases of divorce, thereby affirming their agency as decision-making adults.

After explaining how dignity takings occur in marital property division, I explore the notion of dignity restoration by showing how state law is driving change in traditional perceptions of matrimonial property rights. I demonstrate how the arbitral decisions of a government agency mandated to protect the rights of women and children are facilitating a living customary law of matrimonial property. As a concept, living customary law is described in mainstream literature as the flexible norms that govern people's daily lives, but is easier understood as the norms that emerge from people's adaptation of customs to socio-economic changes. ${ }^{13}$ These norms

11 Atuahene (n 8) 796.

12 Atuahene 818.

13 AC Diala 'The concept of living customary law: A critique' (2017) 49 Journal of Legal Pluralism and Unofficial Law 143. 
may be contrasted with customs which people have not adapted to socio-economic changes, which may be described as non-living customary law. ${ }^{14} \mathrm{I}$ argue that an 'adaptation view' of living customary law is significant for the notions of dignity taking and dignity restoration, since the application of customary law must keep pace with contemporary ideas and attitudes.

The article is informed by semi-structured interviews and focus group discussions with 86 purposively selected female divorcees, their parents, clergy, traditional leaders, non-governmental organisations (NGOs), judges and social welfare officials. These surveys were held between June 2014 and January 2015 in Southern Nigeria, a generally homogenous, predominantly Christian area with a population of approximately 30 million people. ${ }^{15}$ The surveys targeted individuals operating in social fields in which the traditional philosophy of customary law denies women's matrimonial property rights. In fact, in some of these social fields women are regarded as properties - that is objects of inheritance through levirate marriage. ${ }^{16}$ In the context of this traditional philosophy, they are unable to assert matrimonial property rights. This philosophy, also referred to as non-living customary law, is traceable to the agrarian social settings in which customary law emerged. Two features of this social setting are worth noting for the notion of dignity takings.

First, the concept of 'family' was usually expansive, since it comprised not only spouses and their children, but also uncles, nephews and cousins, all of whom worked as a unit to produce property. ${ }^{17}$ Family property was very basic and, other than land, chiefly consisted of communal huts, mats, livestock, economic trees, fishing nets, ritual symbols, kitchen utensils and farming tools. There were no modern gadgets such as cars, refrigerators, computers, television sets and rented apartments. In this close-knit social setting, inheritance was only through the eldest male child, followed by the next senior son, failing which inheritance fell on uncles. ${ }^{18}$ This socalled rule of male primogeniture automatically excluded women. It was justified on the need for an authority figure (the family head) to safeguard family assets and ensure the economic maintenance of widows, unmarried daughters and teenage sons. ${ }^{19}$ This agrarian social

14 As above; AC Diala 'Judicial recognition of living customary law in the context of matrimonial property rights in South-East Nigeria' PhD thesis, University of Cape Town, 2016.

15 This is an estimated figure. The 2006 national census puts the region's population at 16,4 million.

16 CJ Korieh 'Widowhood among the Igbo of Eastern Nigeria' MA dissertation, University of Bergen, 1996 ch 3.

17 CN Himonga 'Property disputes in law and practice: Dissolution of marriage in Zambia' in A Armstrong \& W Ncube (eds) Women and law in Southern Africa (1987) 61-66.

$18 \mathrm{~N}$ Okoro The customary laws of succession in Eastern Nigeria and the statutory and judicial rules governing their application (1966) 4-6.

19 As above. 
setting birthed the customary law philosophy of non-matrimonial property rights for women, a philosophy similar to feme covert. Also called couverture or coverture, feme covert was a legal doctrine in medieval Europe, in which a married woman's legal rights and liabilities were subsumed by her husband's rights. As Blackstone described it,

the very being or legal existence of the woman is suspended during the marriage, or at least is incorporated and consolidated into that of the husband, under whose wing, protection, and cover, she performs everything; and is therefore called ... a feme covert. ${ }^{20}$

After encountering this feme covert-like philosophy, colonial courts created the official customary law that prevents women from exiting marriage with properties other than their clothes and cooking utensils. $^{21}$ Considering contemporary settings of urbanisation, sophisticated forms of household property, and women's contributions to property acquisition through their independent income, adherence to this official customary law during divorce amounts to the infantilisation of women.

The second feature of customary law's agrarian origin is that the woman physically leaves her community after the payment of her bride wealth and joins the husband's family. This movement, which still largely exists, occurs in a manner that makes it clear that she is subordinate to her husband. ${ }^{22}$ As Radcliff-Brown summarised it, 'marriage involves some modification or partial rupture of the relations between the bride and her immediate kin ... and gives the husband and his kin certain rights in relation to his wife and the children she bears'. ${ }^{23}$ The woman's relocation to a different family setting brings her within the ambit and control of her husband's property rights in, as explained, a philosophy similar to feme covert. Notably, up to the twentieth century, feme covert was applied in the Anglo-American legal tradition with an accompanying duty of care from the husband to the wife. ${ }^{24}$ In Nigeria, however, even though a man's duty to care for his family is a foundational value of customary law, ${ }^{25}$ judges rarely utilise this duty to order maintenance or compensation for women after divorce. ${ }^{26}$ Unable to assert matrimonial property rights under customary law, and unprotected by

20 W Blackstone Commentaries on the laws of England, Vol 1 (1976) 443-445.

21 SNC Obi et al The customary law manual (1977).

22 P Iroegbu Marrying wealth, marrying poverty: Gender and bride wealth power in an African society: The Igbo of Nigeria (2007).

23 AR Radcliffe-Brown \& D Forde African systems of kinship and marriage (1950) 43-51.

$24 \mathrm{H}$ Hartog Man and wife in America: A history (2000) 146.

25 E Nwogugu Family law in Nigeria (2014) 59-60; FDI Jones Ibo and Ibibio-speaking peoples of South-Eastern Nigeria (1950) 18; TO Elias Groundwork of Nigerian law (1954) 288-289; SNC Obi Modern family law in Southern Nigeria (1966) 366-371.

26 Patriarchal perceptions of matrimonial property rights are the main reason for judges' reluctance to invoke this duty of care in Nigeria. See AC Diala 'Legal pluralism and social change: Insights from matrimonial property rights in Nigeria' 
Nigeria's legislative framework, women in the process of divorce are routinely robbed of property. This robbery is shrouded in strong, patriarchal gender relations, which denies married women's economic and emotional agency as contributors to matrimonial property acquisition. The result of this denial is disrespect, dependence and legal helplessness in divorcing women, which amounts to infantilisation.

Following this introduction, part 2 of the article applies the notions of dignity taking and dignity restoration to matrimonial property rights. In so doing, I attempt to overcome conceptual barriers to the application of dignity takings to matrimonial property tussles in Nigeria. Thereafter, I problematise the conceptualisation of dignity restoration in context-specific cases involving non-state actors. In part $3 \mathrm{I}$ introduce the Social Welfare Department, a government agency statutorily mandated to protect the interests of women and children. I identify this agency's role in contestations over custody of children, properties brought into marriage by women, and properties acquired during the subsistence of marriage. In part 4 I innovatively analyse the role of the Department in the privileging of gender, class and dignity in matrimonial property. I situate the Department's influence within a legal pluralistic framework, one in which dialogue between customary law and state law manifests in the Department's quasi-judicial orders on marital assets division, the custody of children and child and spousal maintenance. I explore whether these orders contribute to 'dignity restoration' for women previously ignored by the non-living customary law of matrimonial property. In part 5 I conclude by drawing attention to the potential that dialogue between customary law and state law holds for theoretical perspectives on legal integration in Africa.

\section{Dignity takings in matrimonial property disputes}

Applying the notion of dignity takings to matrimonial property disputes in Nigeria could face some conceptual barriers. First, it may be asked whether dignity takings apply to the non-living customary law of matrimonial property, especially in Southern Nigeria. To be clear, two elements are required for a dignity taking to occur. These are 'involuntary property loss plus either dehumanisation or infantilisation'. ${ }^{27}$ Underpinning these two elements is the concept of dignity, of which the jurisprudence is well known. It suffices to identify the two core components of dignity: 'equal human worth and autonomy' ${ }^{28}$ The first conceptual barrier may be framed as a

in C Rautenbach \& S Mancuso (eds) In the shade of an African baobab: Tom Bennett's legacy (2018) 166-167.

27 Atuahene (n 8) 804.

28 Atuahene 800 . 
question: Who is responsible for dignity takings in matrimonial property disputes?

\subsection{Responsibility for dignity takings}

It is too simplistic to offer non-state actors as the sole answer. The non-living customary law of matrimonial property epitomises 'the invisible, constant, and normalised oppression of women' in sociocultural relations. ${ }^{29}$ Since the state has appropriated to itself regulatory power over behaviour, it behoves on it to curb all customary law behaviour which demeans, infantilises and dispossesses women of marital property. Most constitutions provide for human rights to bind the state, its agents and private individuals. ${ }^{30}$ For example, section 34(1) of the Nigerian Constitution provides that '[e]very individual is entitled to respect for the dignity of his person, and accordingly, no person shall be subject to torture or to inhuman or degrading treatment'. Despite defaulting to the male pronoun, this provision protects a woman's right to dignity, which is violated when she is kicked out of her matrimonial home and robbed of a share in her matrimonial property. ${ }^{31}$ Importantly, she is infantilised when her agency is denied over marital property which she bought or helped to acquire with her independent income. For enabling this situation, both the state and the individuals who rob women of matrimonial property are liable.

\subsection{Is the notion of dignity takings applicable to marriage?}

The heading above captures the second conceptual barrier to the application of dignity takings to matrimonial property division under customary law. While dignity takings may not apply to a 'happy' marriage, the same cannot be said for divorce. In an analytic sense, the separation of a married woman's legal status from her husband's is of recent origin under the common law legal tradition. Prior to this separation, the extent to which involuntary property loss constituted dignity taking under the doctrine of coverture was unclear. In his case analysis of coverture in the Anglo-American legal system of the late twentieth century, Hartog rules out coverture as constitutive of dignity taking. ${ }^{32}$ He critiques literature arguing that coverture is 'an inevitable consequence of marriage, [which] implicitly infantilized women [and] kept them from being recognized as autonomous adults'. ${ }^{33}$ He draws a distinction between marriage as dignity taking and coverture as an aspect of marriage that leads to dignity taking. Citing reasons such as

29 Atuahene (n 10) 180.

30 See, eg, sec 8(2) of the 1996 Constitution of South Africa, and sec 34(1) of the 1999 Constitution of Nigeria.

31 UC Isiugo-Abanihe 'Reproductive motivation and family-size preferences among Nigerian men' (1994) 25 Studies in Family Planning 149 at 154.

32 H Hartog 'Coverture and dignity: A comment' (2016) 41 Law and Social Inquiry 833.

33 Hartog (n 32) 835. 
love, choice and the cultural respect conferred by marriage, he argues that marriage does not automatically 'produce a loss of dignity ... [and is also] the antithesis of an "extraordinary" taking'. ${ }^{34}$ However, his focus was on coverture within an ongoing marriage, not as a divorce doctrine in a society where non-living customary law denies women's matrimonial property rights. Importantly, the twentieth century Anglo-American legal tradition he analysed did not deny divorced women maintenance or compensation rights. Indeed, Hartog admits that invocations of 'coverture would include many separated wives ... suing to require husbands to support them, to provide for their "necessaries"'.35 Although 'suing to require husbands to support them' indicates some sort of agency, it hints at action against an infantilised property rights regime. My concern here is with something much more invidious. One aspect of the problem is a philosophy of customary law which regards divorcing women as unworthy of benefiting from property division, irrespective of their contribution to the acquisition of marital property. The other aspect is a total absence of a legal platform for redressing this situation. This combination of official/non-living customary law and an indifferent legal framework often results in a multi-pronged humiliation of homelessness, property theft and disrespect of women's agency over their contributions to property acquisition. To be clear, these contributions are made through women's independent income and emotional support to their husbands. Such an unreasonable philosophy clearly infantilises women and, in some cases, could even be dehumanising. In any case, the rich jurisprudence on domestic abuse shows that dignity takings can occur in subsisting marriages.

One may argue that dignity takings do not apply to matrimonial property because some women elect not to contest property during divorce. In other words, it may be argued that the element of involuntary property dispossession is not present. This argument, however, cannot be sustained when one fully considers the structural barriers and unequal power relations within which matrimonial property rights are asserted and denied. As Pils's study of evictions in China shows, dignity takings also occur when state structures restrict citizens from mobilising to assert their rights, or when state structures erect insurmountable barriers that promote property dispossessions. ${ }^{36}$ Many divorcees told me that they did not bother to contest marital property, not because they did not want to, but because it would be in vain. As a long-divorced woman wryly summarised it, 'I had not gotten that idea that it [matrimonial property rights] operates in Nigeria or even in Africa. So, I thought it was only the Europeans that have that. ${ }^{37}$ Arguably, women's defeatism is induced or exacerbated by their legally insecure status, while their emotional and financial

34 As above.

35 Hartog (n 32) 837.

36 E Pils 'Resisting dignity takings in China' (2016) 41 Law and Social Inquiry 888.

37 Interview with a divorced school principal on 29 July 2014 in Owerri. 
distress negates the voluntariness of their property loss. In fact, the heartrending circumstances surrounding divorce in Southern Nigeria epitomise the demeaning socio-cultural position of women under customary law. The denial of women's matrimonial property rights, therefore, qualifies as a dignity taking worthy of dignity restoration. In this sense, should dignity restoration be state-driven, or could it be initiated by non-state actors such as family members, community leaders and women themselves? This question is significant for the scholarly conceptualisation of dignity restoration.

\subsection{Problematic conceptualisation of dignity restoration}

Dignity takings and dignity restoration originally were used in a vertical sense - that is in the sense of state-initiated property dispossessions, usually justified by legislation or public purpose. Unlike the South African context of dispossession within a state-sanctioned apartheid system, the non-living customary law of matrimonial property in Southern Nigeria is practised largely by non-state actors. However, given the total absence of state regulation of customary marriage and its proprietary consequences, these actors arguably behave with practically no legal restraint, and in contravention of the right to human dignity. In this sense, if dignity takings apply to their conduct, should dignity restoration be the exclusive preserve of the state and its agents? Regrettably, the present conceptualisation of dignity restoration indicates state-centricity as it includes the element of process. ${ }^{38}$

Atuahene defines dignity restoration as 'a remedy that seeks to provide dispossessed individuals and communities with material compensation through processes that affirm their humanity and reinforce their agency.$^{39}$ She identifies restitution, redistribution, reparations and restoration as the constitutive elements of dignity restoration. ${ }^{40}$ These elements are, as she affirmed, 'process-oriented terms' ${ }^{41}$ In my view, however, process is not suitable for involuntary property losses perpetrated by non-state actors. The requirement of process in the definition of dignity restoration obviously flows from the state-centric nature of its original conceptualisation. Fortunately, Atuahene admits that the occurrence of dignity restoration 'is context specific and contingent on a host of factors'. ${ }^{42}$ In what follows, I show why the conceptualisation of dignity restoration should be stripped of its requirement of process.

By requiring process, the conceptualisation of dignity restoration implies system, procedure, or mechanism, all of which are attributes of the state. Arguably, process implies verticality - that is a hierarchical

\footnotetext{
38 Atuahene (n 8) 57.

39 Atuahene (n 10) 818.

40 Atuahene 802.

41 As above.

42 Atuahene (n 10) 814.
} 
relationship. There is no reason why dignity restoration should not be given a horizontal slant to accommodate the increasing realisation that private actors' violations of human rights demand asymmetric solutions. ${ }^{43}$ Such solutions could circumvent and complement the slow, bureaucratic officialdom of the state. Accordingly, dignity restoration in many cases may best be implemented by non-state actors such as family members, friends, arbitrators and community leaders. Indeed, divorcing women's resistance to property deprivation could constitute dignity restoration, in line with Pils's case study showing how acts of resistance against dignity taking could be a form of dignity restoration. ${ }^{44}$ In the foregoing context, I redefine dignity restoration as 'a remedy that seeks to provide dispossessed individuals and groups with material compensation in a manner that affirms their humanity and reinforces their agency'. I now turn to an innovative analysis of the role of a Nigerian government agency in dignity restoration for divorcing women.

\section{Welfare Department and dignity restoration}

The first time an informant stated that 'some relatives referred me to Welfare', it did not strike me as important. I knew 'Welfare' is the colloquial term for the Nigerian Social Welfare Department, but I assumed that the Department's role was conciliatory, not adjudicatory. However, when two other informants mentioned 'Welfare', I was compelled to investigate.

The Welfare Department traces its origins to missionary activities and colonial policies. ${ }^{45}$ At the federal level, it operates as a parastatal under the Ministry of Women Affairs and Social Development. Elsewhere its name varies. ${ }^{46}$ It has offices in almost every municipality in Nigeria, and functions with a policy guide.47 Although it is mandated to promote the interests of women and children, the depth of its involvement in matrimonial property disputes is noteworthy. In January 2015 I visited their offices in two municipalities, observed their dispute resolution mechanisms, and held individual interviews and focus group discussions with their directors, deputies and 11 other officials.

43 M Thornton 'The cartography of public and private' in M Thornton (ed) Public and private: Feminist legal debates (1995) 2; I Currie \& J de Waal The Bill of Rights handbook (2005) 41.

44 Pils (n 36).

45 O Ayodele \& PA Edewor 'Sociology and social work in Nigeria: Characteristics, collaborations and differences' (2013) 16 African Sociological Review 48.

$46 \mathrm{Eg}$, it is called Ministry of Social Welfare and Rehabilitation in Rivers State.

47 This guide is known as 'Social Development Policy for Nigeria', a document adopted in October 1989 and revised in 2004. 


\subsection{Procedures of the Welfare Department}

From my interaction with divorcees, the Welfare Department is the first port of call when families, churches or friends of quarrelling couples fail to resolve matrimonial disputes. There are several reasons for women's resort to the Department. The key reasons are helplessness in the face of the traditional philosophy of matrimonial property or non-living customary law, faith in the strong, coercive shadow of state law, and, of course, the success stories of other divorcees. Curiously, women rarely seek police protection because of strong patriarchal perceptions of women's rights and the police's reputation for corruption. It goes without saying that recourse to the Department is made in the context of marriage under both customary law and state law, in this case the Marriage Act. ${ }^{48}$ These double marriages are common in Nigeria, mainly due to the lack of statutory protection for customary marriages and the failure by non-living customary law to recognise women's matrimonial property rights. ${ }^{49}$ This non-recognition encourages normative shopping - that is, reliance on another legal order to utilise its perceived benefits. ${ }^{50}$ Thus, the Welfare Department stands at an important intersection between customary law and state laws of marriage. As some of the Department's senior officials explained in a focus group discussion, the following describes their dispute resolution procedure: ${ }^{51}$

They [disputants] first write a statement as a report. After that, we issue an invitation letter to the respondent. Then we fix - two weeks or three weeks hearing date. On that day, the parties are expected to come with their witnesses. The report of the complainant will be read out openly to the floor to discuss. After that, we ask the respondent whether the statement is right or not. When he accepts, the case will start. After the first hearing ... we may decide to adjourn to calm the situation.

When a matrimonial dispute is not resolved, the Department proceeds to make varying separation-related orders. An official summarised it as follows:

48 The Marriage Act, Cap 218, Laws of the Federation of Nigeria 1990; Cap M6, LFN 2004.

49 M Onoka Family law (2003) 143; O Agbede 'Recognition of double marriage in Nigerian law' (1968) 17 International and Comparative Law Quarterly 735; AC Diala 'Legal pluralism and social change: Insights from matrimonial property rights in Nigeria' in C Rautenbach \& S Mancuso (eds) Festschrift of Thomas Bennett (2018); Ohochuku v Ohockuwu (1960) 1 ALL ER 253; Jadesimi v Okotie Eboh (1996) 2 NWLR 128 147-148.

50 ES Nwauche 'Legal pluralism and access to land in Nigeria' in H Mostert \& TW Bennett (eds) Pluralism and development: Studies in access to property in Africa (2012) 59-60 70; A Griffiths 'Reconfiguring law: An ethnographic perspective from Botswana' (1998) 23 Law and Social Inquiry 587.

51 Focus group discussions held with 14 officials on 13 and 14 January 2015 in Owerri. The arbitration procedure was explained by Mr Chidi Ucheghara, Senior Social Welfare Officer, Ms Antonia Nwambara, Assistant Social Welfare Officer, and a female official who spoke anonymously on 14 January 2015. The quotes of officials who requested anonymity are used without referencing. 
[If a case] is not resolved amicably and they didn't agree to stay together, we may ask the man to pay something to the woman as compensation. Then, if they have issues - ie children - that are underage, we will ask the man to take care of the children. That is school, feeding, and health wise. Then the man will secure accommodation for them, because they have to live somewhere ... they cannot just be thrown out ...

The courts treat the decisions of the Department as arbitral awards and, when required, judges summon its officials to give evidence. Although they have no formal enforcement powers, when the need arises Department officials use force to protect the best interests of children:

Where they [couple] don't take our advice, they can go to a higher level like taking it to court ... But in some cases that they don't need to go to court and the man does not want to adhere to our instructions like paying maintenance for the upkeep of the children ... after carrying out investigation and we find out that the man just does not want to provide for the children's upkeep, we use the police to get the man to comply.

Other than ordering maintenance and custody of children, the Welfare Department also makes compensation orders in favour of women. The nature of these orders is dependent on the circumstances of the case concerned. The Department's activities indicate it as an agent of dignity restoration.

\subsection{Dignity restoration agents?}

It is not clear whether the activities of the Department fit the present conceptualisation of dignity restoration. As explained, dignity restoration is a remedy for dignity takings, which occurs in contexts of property dispossession that involve the 'dehumanisation or infantilisation of the dispossessed'.52 While dehumanisation denotes disrespect or non-recognition of a person's humanity, infantilisation denotes the restriction of an adult's autonomy and full capacity for independent action. In other words, infantilisation involves the treatment of an otherwise fully rational and capable adult as a minor. For divorcing women who are infantilised in the course of matrimonial property division, 'providing material compensation is not enough because they lost more than their property - they were also deprived of their dignity'. ${ }^{53}$ Accordingly, they require dignity restoration beyond mere material compensation. While the activities of the Welfare Department clearly provide material compensation in a reasonably respectful or dignity-restoring manner, the element of process is not met. For a start, the Department intervenes in matrimonial property disputes on invitation. Also, it has no formal mechanism for handling matrimonial property disputes. They merely act on the best interests of children principle, from which they extrapolate or submerge a best interests of women principle.

52 Atuahene (n 8) 796.

53 As above. 
Accordingly, their arbitral awards are made on a case-by-case basis, which potentially leaves their decisions open to abuse by corrupt officials. In effect, Department officials do not adjudicate with a dignity-restoration mindset. In other words, they do not set out to redress divorcing women's property dispossession with a view to remedying the non-living customary law philosophy that infantilises women. In the context of the present conceptualisation of dignity, therefore, dignity restoration in the Department's arbitral orders may be regarded as accidental. The cases below demonstrate the complex circumstances of dignity takings, which make it difficult for process to be an element of dignity restoration.

\subsection{Manifestations of dignity taking}

To understand the circumstances of dignity takings in matrimonial property disputes, I must first explain marriage gifts, which constitute a key aspect of property tussles. Marriage gifts are items given to the bride at the time of her marriage to assist her transition into the marital journey. These items are not to be confused with the gifts brought by a groom as part of the requirements of bride wealth. ${ }^{54}$ In the past, marriage gifts consisted exclusively of cooking utensils and items of adornment such as jewellery, clothes and sandals. They presently include modern gadgets such as cars, refrigerators, television sets, dishwashers and furniture.

There are two broad categories of marriage gifts. The first category comprises items given to a bride by her parents and extended family. The second category comprises gifts given to the couple by their friends. This category may also include gifts given to the bride by her friends specifically or generally for her comfort. Examples are cars, laptop computers, household furniture, kitchen utensils, business equipment, and items of adornment such as clothes and jewellery. As explained below, this second category presents problems during marriage dissolution, given the difficulty of determining whether such gifts are meant for the couple or only for the comfort of the woman. The following representative stories from pseudonymised informants reveal how divorcees, traditional leaders, NGOs, priests and Welfare Department officials treat women's matrimonial property rights in and outside the courts in Southern Nigeria. ${ }^{55}$ Importantly, they show the cultural, legal and psychological issues within which unequal power relations and dignity takings occur.

\subsubsection{Quality of legal services}

Janet and John married in 1992. They had four children. John, a businessman, accused Janet of infidelity. Janet, a civil servant, accused him of violent domestic abuse. John eventually chased her away from

54 J Osom 'Moral implication of high bride-price in Nigeria: Annang case survey' PhD thesis, Pontificia Universitas Lateranensis, 198934.

55 In all these stories, I have protected the identity of informants with pseudonyms. 
their matrimonial home and petitioned for divorce in a customary court. Initially, both parties were not legally represented. Janet told the court she wanted custody of her children, even though she did not want the marriage to be dissolved. She briefed her lawyer to claim her marriage gifts and seek maintenance for herself and her children. She later requested compensation for the furniture she had acquired, her contributions to the house they built in the village, and the 200000 naira she contributed to the purchase of their car. ${ }^{56}$ Due to her lawyer's incompetence, her motion, although properly filed, was not argued. Thus, it was struck out and judgment was granted in favour of John, including custody of their children. The court also issued an order restraining Janet from bearing John's surname. Following family advice 'to wait and see if the [love] charm used to bewitch [John] would fall away', Janet did not appeal the judgment. She also did not approach the Welfare Department. Seven years on she is still waiting and has recovered no properties from the marriage.

\subsubsection{Disparate power relations}

Sarah was forced by her parents to marry Samuel in 1999 after she had fallen pregnant. They had two children. Samuel's family gave Sarah a parcel of land as a marriage gift. With her family's help, she set up a catering business, and helped Samuel to acquire household property such as a refrigerator and a television set. She also contributed significantly in building a three-bedroomed house. In 2008 Samuel accused her of prostitution and violently evicted her from their matrimonial home. A few days later Sarah returned to her matrimonial home with her brother to take her business materials. She did not take her clothes and items of adornment as she hoped to reconcile with her husband. A year later Samuel remarried and sent their two children to work as domestic helpers in the city. Following a vicious custody battle involving alleged kidnappings and the use of armed vigilantes, Sarah petitioned their local Welfare Department, who awarded her custody. Samuel refused to comply with the order, allegedly using a combination of threats, bribery and intimidation to avoid enforcement of the custody order. Sarah then petitioned for divorce and custody in a customary court. Samuel showed up with a marriage certificate and claimed that he had undergone a statutory law marriage with Sarah. The court declined jurisdiction, stating that a customary marriage became subsumed in a later statutory marriage. Eventually, Sarah remarried and used direct conciliation to obtain custody of her children. Largely due to Samuel's violent nature and the non-living customary law of matrimonial property, neither Sarah nor her family members contested the couple's household properties. In fact, Sarah never returned to take her clothes, and Samuel's new wife allegedly started wearing them. 


\subsubsection{Futility of formal law}

Gift, a high school teacher, married Gerald, a civil servant, in 2001. They had a child. In 2008 co-habitation stopped after Gerald had used a machete to evict her from their matrimonial home. Three months later Gift returned with her brother, attempting to retrieve her belongings and her baby's clothes. They were unsuccessful as Gerald had changed the locks. Gift later picked up some of her belongings from a neighbour's house where Gerald had dropped them. He looted Gift's shop, claiming that everything they owned belonged to him. Following the failure of several family reconciliation efforts, Gift headed to the Welfare Department.

Gerald initially refused to appear, eventually being compelled by the police to appear. Welfare officials awarded custody of the (then) three year-old baby to Gift. They ordered Gerald to provide accommodation for Gift and pay 6000 naira as monthly maintenance for the baby. He refused to heed the decision and on several occasions tried to kidnap the baby. In 2011 Gift petitioned for marriage dissolution, custody and maintenance of the child. She did not request maintenance for herself as she loathed Gerald and believed that she could take care of herself. Gerald failed to contest the petition, had judgment given against him, and refused to comply with the court order for maintenance. Gift did not enforce the judgment. In her words, 'I cannot force him to train [educate] his own child.'

\subsubsection{Litigation fatigue and resource constraints}

Grace's parents forced her to marry Greg in 1996. They had four children. In 2006 Greg instructed her to leave the city and return to her parents in the village as he wanted to bring back his first wife. Grace, who was unaware that Greg had married two women before her, refused to leave. Several unsuccessful family mediations occurred. Church officials advised Greg to secure accommodation for Grace and educate her children. One morning in 2008, Greg used a lorry and a van filled with police officers to forcefully repatriate Grace to her parents' house. A month later Grace reported him to the Welfare Department, who made the same orders as the church. Greg agreed to obey the order by a certain date. In the meantime, Grace went to the city and 'rescued' her children who were being ill-treated by Greg's first wife.

A few days prior to the deadline of the Department's order, Greg petitioned for divorce and custody in a customary court. Assisted by a human rights lawyer, Grace successfully counter-claimed for custody, payment of her children's tuition, monthly maintenance of 100000 naira for the children, monthly maintenance of 50000 naira for herself, and 5000000 naira 'damages' for 'untold hardship' and 'deceit'. Following intense litigation, the court granted Grace's extraordinary claims for dignity restoration. 
Greg appealed, lost, and appealed again. The case stalemated. The human rights lawyer moved on. Tired of the emotional, physical and financial drain of litigation, Grace reached an out of court settlement, wherein Greg agreed to fund the children's education and Grace agreed to abandon all other claims. She took only her 'personal belongings' out of the marriage.

\subsubsection{Self-restoration of dignity}

At the age of 15 Sandra's parents forced her to marry Simon, a wealthy businessman in his fifties. The couple resided in Simon's twostorey building in a peri-urban area and had three children. Simon had earlier married two women at different times and 'driven them away' after some years. For nearly a decade he allegedly used Sandra as a slave, while failing to fulfil the financial promises he had made to her parents, which notably included building them a house. Emboldened by age, socialisation and education, Sandra began resisting her husband's abuse. Problems ensued. A now aged Simon accused her of infidelity, theft and cruelty, and attempted to use a rifle to evict her from their matrimonial home. She seized the rifle and instead evicted him. He petitioned for divorce in a customary court and the reclaim of their matrimonial residence. He obtained judgment allegedly by fraud, and Sandra's lawyer quashed it on appeal. While the matter was being retried at another customary court, Simon died. Family members divided his estate according to 'kitchens'. ${ }^{57}$ They gave Sandra the two-storey building she was occupying with her children. Simon's two widows received his other properties, notably buildings. During her interview Sandra admitted that the widows would have received no properties if they had no male child. She decided to 'take matters' into her our hands mainly because of her education, socialisation, and Simon's unfulfilled promises to her parents.

\subsubsection{Family involvement in dignity restoration}

Linda, a teacher, married Linus, a lecturer, in 1991. Both hailed from the same town and lived in the city. The marriage produced two boys and a girl. After 12 years Linus's repeated domestic assaults on Linda compelled the couple to live apart. Linda obtained access to their children with the help of the Welfare Department. Unable to reconcile the parties at one final family meeting attended by 12 persons, the couple were permitted to separate. The families ordered Linus to regularly pay 'something for the upkeep of the kids ... especially for their schooling'. They made no order for Linda's maintenance, nor did she demand it. Similarly, they did not order a division of the couple's car, house and household furniture. Linda merely took her 'personal

57 Division according to kitchens or 'houses' means division of a deceased's estate according to the number of his wives, especially those with a male child. See, generally, DSP Cronje \& J Heaton South African family law (2010) 210-211. 
effects - boxes, dresses, [and] some of the kitchen utensils'. After a period of refuge in her uncle's house, she obtained her own apartment. Unlike Linus, she never remarried and still bears his surname. Following their non-judicial divorce, she never claimed matrimonial property, even after Linus died four years later.

\subsection{Dignity restoration in matrimonial property disputes}

The circumstances in which many women leave their matrimonial homes in the above stories obviously discourage them from contesting marital property. More than anything else, the unequal power relations evident in these stories, coupled with women's loss of their matrimonial home, contribute to dignity takings. There are emotional, cultural and even religious values attached to property, including matrimonial property. In the case of the matrimonial home, these values sometimes outweigh economic values. As Atuahene argues, 'a home is more than a physical structure; it is a claim to a specific space that places a person in proximity to particular people with whom they form relationships'.58 The question is whether dignity restoration applies to matrimonial property disputes in Nigeria. I argue that it applies if the element of process is removed from the definition of dignity restoration. Women's dignity may be restored through property division, monetary compensation and, above all, the legislative recognition of women's matrimonial property rights. While process may be involved in some of these measures, it need not be a requisite element of dignity restoration.

In the remainder of the article I reveal the shadow of state law in the privileging of gender, class, and dignity in matrimonial property division. In so doing, I draw attention to the adaptive influence of state law on social fields involving customary law.

\section{Dignity restoration in the shadow of legal pluralism}

As hinted in part 3, other than customary courts and the 1999 Nigerian Constitution, I did not know that a state organ such as the Welfare Department was influential in people's application of customary law. ${ }^{59}$ In what follows I analyse the creative ways in which the Department is involved in dignity restoration for divorced women dispossessed of property by the non-living customary law of matrimonial property.

\subsection{Use of receipts}

Obviously, the means through which dignity restoration can be achieved are not just context-specific but also debatable. The contexts include 'the political and economic power of the victims, the level of

58 Atuahene (n 10) 172.

59 Indeed, my original interview plan did not include the Welfare Department. 
political will among powerbrokers ${ }^{60}$ and, in this article, the legal framework. The first key tool in the Department's recovery of marriage gifts and properties bought by women are purchase receipts. This reliance on receipts as evidence of matrimonial property contribution is influenced by judicial trends. ${ }^{61}$ In Janet's case above, the judges ruled that it was insufficient for her to allege contributions to matrimonial property without tendering evidence. Traditional rulers, clergy and staff of NGOs affirmed that women may claim matrimonial property with receipts showing that the property was bought in their own name. The problem, as a female Department official said, is that 'when making receipts, [women] use their husband's surname. When there is any dispute, the husband will now claim the property.' The use of receipts is because non-living customary law regards women's property rights as derived from their husbands. ${ }^{62}$ A Department official expressed it as follows:

In [non-living] customary law, the woman is a loser as far as divorce is concerned. She goes home almost empty-handed. The man owns the property except where the woman bought certain things with her own money. In such a case, she has to prove that those things really belong to her because the [non-living] customary law says that the man owns the woman and all her property. If she has no receipts, the community [extended family] may, out of pity, grant some part of what the woman is asking for ...

There is near unanimity among my informants that a divorcing woman should exit marriage with the properties she received as marriage gifts from her parents. However, she generally forgoes properties received from friends in her marital name, unless her husband or family members allow her to take them. This is regardless of whether these properties were given by her own friends. Since they bear the marital name, usually the man's family name, they are presumed to belong to the man. In this clear denial of women's agency in marital property acquisition, the Department makes significant interventions, as I explain below.

The couple is usually asked to list their properties and provide evidence of acquisition. Where the purchase receipt of a marriage gift, or indeed any matrimonial property, discloses that it was acquired in the woman's name during the subsistence of the marriage, the Department decides in the woman's favour. An official, Mr Emeka Okpara, explained it as follows: ${ }^{63}$

60 Atuahene (n 8) 814.

61 Eg, in Onwuchekwa v Onwuchekwa (1991) 5 NWLR (Pt 194) 739, the Court of Appeal held that a wife must tender 'sufficient proof' such as 'receipts' showing her contribution to matrimonial property. See also Amadi $v$ Nwosu (1992) NWLR (Pt 241) 273; (1992) LPELR-442 (SC).

62 In Onwuchekwa (n 61), the Court of Appeal surprisingly confirmed an Isuikwuato (Abia State) custom, which holds that a wife and her properties are owned by her husband.

63 Interview conducted on 13 January 2015 in Owerri. 
First, we ask them to list the property. If it is property that should come with receipts, for instance, like cars, houses, and land, in that type of case, we will ask them to produce receipt. If that receipt has only that person's name, then it automatically belongs to that person. But if it is written to the woman's name, we will give it to her, because definitely, it is her that bought the thing with her money.

Where the property is acquired in the couple's name, usually the man's name or family name, the Department is inclined to rule equitably, or in the woman's favour. Their decision is influenced by factors such as income capacity, the quantum of properties, custody of the children, and fault. An official in a focus group discussion stated without contradiction:

If it is joint property, we check the numbers - for example foam [mattress] - if the woman is seeking to separate from the man, you don't say 'go and lie on the floor'. You check the number of the foams. If it is two, let me say for instance, you give the woman one and the man will collect one. And more especially if ... the children are under age, you don't allow the children to sleep on the floor ... Even if the foam is one, you give the children that foam ... because the child is our main priority in handling matrimonial matters.

This official's statement reveals the influence of the best interests of the child principle in the Department's arbitral decisions. This principle, which forms part of the foundational values of customary law, $^{64}$ is the second key element in matrimonial property division after divorce.

\subsection{Children's connection}

Department officials make special efforts to uphold the best interests of the child in their decisions on custody. This is in furtherance of legislation such as the Child Rights Act of 2003 and the Children and Young Persons Act of 1943, as variously amended in the eastern, western and northern regions of Nigeria. The Department's efforts are also a recognition of the foundational value of customary law which holds that a man must care for his family. In this light, the best interests of the child principle demonstrates resonance between customary law and state law. As two officials put it, 'we [also] rely our judgments on the law of the land - that is the customary law ... the Igbo tradition values children - whether male or female child'. ${ }^{65}$

Although the traditional philosophy of customary law ascribes custody to men, the best interests of the child principle is shifting this philosophy. In explaining this shift, Mr Chidi Ucheghara stated: ${ }^{66}$

In customary law, the man and the woman both own the children. But custody depends on the age. If the child is like zero to six years, custody

64 See $n 14$.

65 Interviews with Mr Emeka Okpara, Social Welfare Officer, and a female official who spoke anonymously at Owerri on 13 January 2015.

66 Interview with Mr Chidi Ucheghara, Senior Social Welfare Officer on 14 January 2015 at Owerri. 
will be awarded to the mother. But if the child is up to twelve years, the child can be under the custody of his father.

The stress on the phrase 'can be' shows that custody is no longer the automatic preserve of men. Given the huge clientele of the Welfare Department, it is obvious that

their attitude to custody is contributing to the emergence of a living customary law of child custody. One may then ask, 'What about childless couples?' The next section discusses the motivations behind the Department's dignity restoration attitude to childless divorcees.

\subsection{Dignity restoration for childless women}

Ordinarily, non-living customary law does not recognise maintenance for divorced women except, as seen above, through the duty to care for children. Indeed, some of my divorcee informants seemed surprised at the possibility of obtaining maintenance. Others credit the Welfare Department for its increasing orders relating to maintenance. For the Department the issue is not whether divorced women are entitled to maintenance. The issue is whether their orders should be termed compensation or maintenance. This dilemma is an aspect of the gendered and psychological realities of divorce. For the Department, maintenance is a regular sum paid to a spouse by the other. Conversely, compensation is a lump sum paid by a spouse to enable the other to set up a business or make up for the financial loss caused by the divorce. Compensation obviously is a muted recognition that divorce in Southern Nigeria usually involves involuntary property loss which requires remedial action.

Furthermore, the Department's compensatory orders acknowledge unequal power relations between men and women. Maintenance implies an element of control on the part of the person providing it. As an official explained, 'If you say maintenance, that means you will even house her, and monitor the house. If she brings a man there, you will know and go there to throw the man away.' A key reason why the Department prefers compensation to maintenance is the incredible emotional distress involved in divorce cases. Several informants affirmed that they would never accept maintenance from their former husband as it would prevent them from having 'proper closure'. ${ }^{67}$ Some only accept maintenance on behalf of their children because they cannot raise the children on their own. They generally prefer not to ask for any financial relief unless they cannot help it. Indeed, a study found only three judicial decisions in which women demanded compensation after divorce. ${ }^{68}$ In Grace's case study above, she termed it 'damages' for 'untold hardship' and 'deceit'.

67 Obiora's probe of attitudes towards financial awards during divorce suggests that women 'found it contradictory to supplicate for help from former husbands who had maltreated and/or betrayed them'. See LA Obiora 'Kindling the domain of social reform through law: A case study' (1995) 13 Third World Legal Studies FN 65. 
Department officials take the issue of compensatory orders seriously. If a man refuses to comply with an order of compensation, they could use law enforcement agents to enforce it, or assist the woman to institute court proceedings. Remarkably, compensatory orders are made irrespective of whether children are involved. $\mathrm{Mr}$ Okpara explained it as follows: ${ }^{69}$

If the woman is without a child or children, you don't pay any maintenance to her. But rather, we advise the man to compensate the woman so that the woman will use the money to be maintaining herself. If you ask the man to be maintaining the woman, it then means that you are asking the man to be controlling the woman because he who pays the piper, dictates the tune ... If you have advised the man to pay compensation and he refuses to pay it, you now apply force to take it.

The amounts of compensatory orders made by the Department are usually dependent on the circumstances of the divorce. These circumstances include the financial status of the couple; the extent of the woman's contribution to the matrimonial property; the party at fault in the divorce; the length of the marriage; and the possibilities of the woman remarrying. Mr Mbawuike Richard explained: ${ }^{70}$

If the man was instrumental to the dissolution of that marriage, under customary law, there is nothing that binds the man to maintain the woman. She just goes. But here in Social Welfare Department, we ask the man to compensate the woman - give her some money. The sum is dependent on the status of the man. So, we ask the man to give the woman a sum, which she can use to rehabilitate herself.

The most striking aspect of the Department's interventions in matrimonial property disputes is the context-specific nature of its decisions. Their case-by-case approach, which resembles common law judges' approach, ${ }^{71}$ makes it difficult for process to form an essential element of the definition of the dignity restoration. In the concluding part of this article I argue that the Department's activities demonstrate dialogue between state law and customary law, which aids the emergence of a living customary law of matrimonial property in Southern Nigeria.

\section{Significance of state law's dialogue with customary law}

In non-judicial divorce, the Welfare Department increasingly orders men to give financial compensation to women. Its compensatory orders are dependent on the circumstances of each case, notably fault, the woman's contribution to the matrimonial property, and the earning status of the parties. Not only do they routinely award

69 Interview held on 13 January 2015 in Owerri.

70 Interview held on 14 January 2015 in Owerri.

71 Diala (n 14). 
custody to women, but these officials also order men to pay maintenance for the children. For deviating from the non-living customary law of matrimonial property, these orders, which have a multiplier effect on normative behaviour in social fields, constitute adaptations of customs to socio-economic changes.

People's adaptations to socio-economic changes produce living customary law when individuals in a social field attach a sense of obligation to new practices or adaptations of existing practices. ${ }^{72}$ Instructively, Welfare Department officials usually belong to the same normative social field as estranged couples. They therefore act with full awareness of the non-living customary law of matrimonial property. Their deviations rightly acknowledge the dissonance between the agrarian origins of matrimonial property rights and the application of these rights in modern conditions. They recognise that women contribute to the acquisition of matrimonial property through their independent income. They also recognise that marriage gifts have moved beyond kitchen utensils to include modern gadgets such as houses, cars, televisions and refrigerators. Significantly, these gadgets are not only bought by the woman's family, but also by the couple's friends. The Department's interventions therefore are positive steps towards dignity restoration for divorced women. Their interventions are also significant for legal pluralism in Nigeria.

As explained in part two, there are no statutory regulations of customary law rules of succession, marriage and divorce in Nigeria. There is also no provision in the matrimonial legal framework for marriage in community of property. ${ }^{73}$ Because of these legislative lacunae, 'the creation of a [customary law] marriage has no immediate effect on the parties' property rights' ${ }^{74}$ My informants unanimously affirmed that 'a woman is a loser' under the customary law of divorce. The word 'loser' is usually used in humiliating contexts in Nigeria. It accurately depicts the legal situation of women, who have little financial protection after divorce, irrespective of the type of their marriage and the extent of their contributions to matrimonial property. ${ }^{75}$ Unfortunately, the Nigerian Supreme Court is yet to recognise women's beneficial interests in matrimonial property. ${ }^{76}$ As it has been severally held in divorce proceedings, women cannot lead evidence of jointly-owned properties by showing acts of ownership

72 Diala (n 13) 150-151.

73 Community of property denotes a marriage of equal property benefits and loss.

74 G Woodman 'Judicial development of customary law: The case of marriage law in Ghana and Nigeria' (1977) 14 University of Ghana Law Journal 127.

75 E Chianu 'The horse and ass yoked: Legal principles to aid the weak in a world of unequals' Inaugural Lecture, University of Benin, 2007 153-154.

76 In Onwuchekwa (n 61) the Court of Appeal held that a wife must show 'sufficient proof' of her contribution to matrimonial property. See also Amadi v Nwosu (1992) NWLR (Pt 241) 273; (1992) LPELR-442 (SC). 
such as paintings and improvements. ${ }^{77}$ In fact, judges used to regard women as inheritable chattel, while legislative lacunae encourage men to dispossess women of their matrimonial property contributions. ${ }^{78}$ Since non-living customary law regards married women's property rights as subsumed in those of their husbands, Nigeria's nonregulation of matrimonial property robs divorced women of a legal platform to contest property. ${ }^{79}$ The absence of this legal platform encourages involuntary property loss and infantilisation, the core elements of dignity takings.

The significance of dignity takings in matrimonial property is accentuated by women's tendencies to acquire property in their partners' names because of their desire to marry or remain married. As studies elsewhere indicate, ${ }^{80}$ this tendency is not peculiar to Nigeria. From my interactions with divorcees, women appear to be more committed to marriage stability than men, thereby preventing them from taking measures to safeguard their financial wellbeing in case of divorce. This situation makes it imperative for Nigeria's legal framework to provide for matrimonial property rights. In the same way involuntary property loss 'can deprive people of dignity', 81 the legislative affirmation of matrimonial property rights can restore women's dignity as individuals with full agency and equal partners in the marriage enterprise. Similarly, judicial or administrative actions, which affirm women's rights to matrimonial property, constitute dignity affirmation. Accordingly, the property division and compensatory orders of the Welfare Department demonstrates dignity restoration for divorced women.

Furthermore, the Department's adjudicatory orders reveal dialogue between state law and customary law. This dialogue is significant for legal pluralism because living customary law emerges from people's adaptation of customs to socio-economic changes. ${ }^{82}$ An adaptation viewpoint fits the notion of dignity takings in matrimonial property, since the application of customary law must keep pace with contemporary ideas and attitudes. Notions of equality, mutual respect and autonomy are inconsistent with the non-living customary law of

77 The Court reasons that such improvements do not divest the property of its original character of family ownership. See, eg, Rabiu $v$ Absi (1996) 7 NWLR (Pt 462) 505 SC (69-70).

78 Aileru v Anibi (1952) 20 NLR 45; Akinnubi v Akinnubi (1997) 2 NWLR (Pt 486) 144; Folami $v$ Cole (1990) 2 NWLR (Pt 133) 445; Amusa v Olawumi (2002) 12 NWLR (Pt 780) 30.

79 Eg, see A Oyajobi 'Better protection for women and children' in A Kalu \& Y Osinbajo (eds) Women and children under the Nigerian law (1990) 29; PO Kuye 'Rights of women under customary law' in Y Osinbajo \& A Kalu (eds) Towards a restatement of Nigerian customary laws (1991).

80 See, eg, AM Richardson 'Women's inheritance rights in Africa: The need to integrate cultural understanding and legal reform' (2004) 11 Human Rights Brief 19-22; LH Fincher Leftover women: The resurgence of gender inequality in China (2014) 3.

81 Atuahene (n 10) 173.

82 Diala (n 13). 
matrimonial property. When this law is applied without consideration for changing forms of household property and women's independent income, dignity takings occur. Given the notoriety of double marriage and the large number of women who patronise the Department, 83 their compensatory and child custody orders are positive normative influences on the customary law of matrimonial property. As shown below, these influences question an antipodal approach to legal pluralism and, simultaneously, encourage legal integration.

\subsection{Inspiration for legal integration}

More than a century has passed since legal transplants occurred in Nigeria and other post-colonial societies. In this period, however, no significant effort has been made to develop a jurisprudence which blends customary law 'with modern Western law and institutions in an appropriate mix'. ${ }^{84}$ Customary law is still perceived as inherently antithetical to state law, especially the Bill of Rights. ${ }^{85}$ However, this need not be so, given that customary law is flexible, adapts to changing social and economic conditions, and possesses foundational values which inform and guide its flexibility.

My field encounters in Southern Nigeria reveal similarities between the foundational values of customary law and some aspects of state law. For example, the family head's duty of care under customary law resonates with the duties of an intestate administrator. The value of humanness under customary law resonates with the right to human dignity under state law. The need to preserve the ancestral home arguably resonates with state laws on cultural heritage. The value of collective liability under customary law resonates with liability under Anglo-Saxon law, which eventually morphed into state law. ${ }^{86}$ In the context of legal integration, therefore, customary law's values of humanness and duty of care to the family can be extrapolated into legislation not only recognising women's matrimonial property rights, but also the spousal right to maintenance or compensation after divorce. Such recognition would affirm women's dignity as equal partners in the marriage enterprise. This is where the Welfare Department provides a model for legal pluralistic dialogue.

83 More than two-thirds of the interviewed divorcees passed through Social Welfare mediation. Nearly all others had contemplated using their services.

84 D Weisbrot 'Papua New Guinea's indigenous jurisprudence and the legacy of colonialism' (1988) 10 University of Hawaii Law Review 30-31.

85 The disdainful treatment of customary law by colonial authorities probably contributes to its subordinate status in African legal systems.

86 F Pollock \& FW Maitland The history of English law before the time of Edward I (1895); TF Plunkett Concise history of the English law (1956) (showing how security, justice, oaths, marriage, wardship and succession were all regulated by the law of kinship). 


\section{Conclusion}

The Nigerian government indirectly contributes to the denial of women's matrimonial property rights by failing to statutorily regulate the proprietary consequences of a customary marriage. This failure brings the state within a complicit human rights relationship with customary law actors who deny women's matrimonial property rights, dispossess them of property, deny their economic and emotional agency, and thereby infantilise them. I have argued that these tripartite elements amount to dignity takings.

I have also argued that the requirement of process in the definition of dignity restoration hinders remedial measures for women humiliated by the non-living customary law of matrimonial property division. These measures may be best implemented in an asymmetric manner devoid of process. Accordingly, I have redefined dignity restoration as a remedy that seeks to provide dispossessed individuals and groups with material compensation in a manner that affirms their humanity and reinforces their agency. The removal of process from the definition of dignity restoration accommodates the contextspecific nature of property dispossession perpetrated by non-state actors.

Even though the conflict of laws in Africa encourages an antipodal approach to legal pluralism in mainstream scholarship, I have focused on dialogue between state law and customary law. I have shown how a government agency, the Social Welfare Department, is influencing normative behaviour through arbitral orders that contravene traditional perceptions of the customary law of matrimonial property. In prosecuting its statutory mandate to promote the best interests of women and children, the Department routinely awards custody of children to women using the best interests of the child principle. It also divides matrimonial property and orders men to pay maintenance or compensation to their estranged spouses. Given the lacunae in Nigeria's legal framework on the proprietary consequences of marriage, these arbitral orders could constitute dignity restoration in the sense I have defined it. The Department's quasi-judicial orders demonstrate the dialogic intersection of state law and customary law on normative behaviour in social fields. These intersections bode well for legal integration in Nigeria. 